\title{
European railway reforms and efficiency: Review of evidence in the literature
}

\section{Hana Fitzová ${ }^{1}$}

\begin{abstract}
The objective of the European railway reforms which started in the 1990s was to enable the entry of competition to raise the efficiency of railway transport. This was undertaken because the level of services, particularly in former Eastern Bloc countries, was very low due to neglected investment, and so railway transport market share was in decline. The primary goal of this text is to determine based on available empirical studies whether the reforms affected the efficiency of the railway sector positively, and the secondary aim is to identify the factors which complicate evaluation of the reforms' impact. According to empirical studies, the effect of competition on efficiency is unclear. The reforms have brought the most benefit to consumers, but their overall effect depends on many other factors. Competition for the market appeared to be a better way of implementing competition than competition in the market. In addition, comprehension of the problems complicating the analysis and their inclusion in the evaluation process constitutes an important point in evaluating the reforms' effects and could be inspiring for countries that have not yet implemented all reforms.
\end{abstract}

Key words: competition, efficiency, European railway reforms, railway transport

JEL Classification: R40, C44, C61

Received: 9 February 2017/ Accepted: 20 April 2017/ Sent for Publication: 8 June 2017

\section{Introduction}

The EU considers railway transport to be an important means of transport for the long term. It eases congestion on roads and is less harmful to the environment than road or air transport is. An important target for European transport strategy is increasing railway transport's share of the traffic market (European Commission, 2001). The European railway reforms which started in the 1990s were a reaction to a number of problematic phenomena, including railway companies' growing financial losses, declining performance, and market share; low levels of services; and insufficient investment, all despite growing subsidies. The main objective of the European railway reforms was to enable competition to enter the existing network in order to increase efficiency in the railway sector.

\footnotetext{
${ }^{1}$ Faculty of Economics and Administration, Masaryk University, Brno, Czech Republic, hana.fitzova@econ.muni.cz
} 
The philosophy of the reforms resulted from the assumptions that the network is a natural monopoly case and operational services are implementable via competition. Infrastructure planning and financing are seen as essentially a state role, while services can be operated on a commercial or subsidized contractual basis (Nash, 2008). According to the European Commission, it was first necessary to split network and operational services in some manner.

There have been four reform packages so far. The First Railway Package (2001) enabled non-discriminatory access for rail operators to the trans-European network for international freight services. The primary action of the Second Railway Package (2004) was to fully open the freight market to competition from 1 January 2007. It has increased the competition and efficiency of rail freight transport as well as the competitiveness of new rail operators. In addition, the package created the European Railway Agency. The Third Railway Package (2007) ensured open access rights could be implemented for international rail passenger transport by 2010 (European Commission, 2016a). Nevertheless, domestic rail passenger services have not yet been opened to EU competition as most of European rail passenger services (around 90\% in 2010) are subject to a public service obligation (CER, 2011). The Fourth Railway Package (2016) contains a technical pillar, comprising proposals for amending interoperability and safety directives and a regulation on the European Railway Agency, and a market pillar, the main goal of which is to open the domestic passenger services market (European Commission, 2013b). The market pillar should be implemented by December 2019. In the majority of cases, competitive tendering for the public service obligation will be obligatory from December 2023.

The aims of this article are to investigate available empirical studies to determine whether the European railway reforms have increased railway sector efficiency and to identify factors which complicate measurement of the reforms' impact.

The paper is structured as follows: Section 1 introduces the basic European railway reforms and summarizes the current state of competition in EU countries. Section 2 reviews the relevant literature. Section 3 describes methods for measuring efficiency in railway transport. Section 4 analyses problems connected to evaluating the effects of the reforms. The conclusion summarizes the presented issues and discusses possibilities for future development.

\section{Basic European railway reforms}

The railway reforms in the EU most often took the forms of vertical separation and entry of competition, although there were also some cases of horizontal separation.

\subsection{Vertical separation}

Vertical separation in Europe took one of three forms - complete separation of infrastructure and operations, creation of a holding company, and a hybrid model called separation of key powers. The first form (complete separation) can be seen when infrastructure is properly separated from operations. In such cases, the infrastructure manager and the incumbent are institutionally separated so as to ensure a more efficient influence from competition and thus lower prices and costs (Thompson, 1997). This can be found in the majority of EU countries - Belgium, Bulgaria, the Czech Republic, Croa- 
tia, Denmark, Estonia, Finland, Greece, the Netherlands, Portugal, Romania, Slovakia, Spain, Sweden, and Great Britain (European Commission, 2016b).

The second form (a holding company) is less frequent than the first. It is found when infrastructure management and operations are divided into detached departments with separate accounting within a single holding company. Planning of investment and capacity use is integrated, and it is necessary to enable entry to other operators. Such a form with limited independence guarantees can be found in Austria, France, Germany, and Italy; such a form with strong independence guarantees in Belgium, Latvia, Poland, and Slovenia (European Commission, 2016b).

There is also a third hybrid form known as separation of key powers, which can be found in Hungary, Ireland, Lithuania, and Luxembourg. It is also called an operational separation model and involves responsibility for certain activities (e.g. capacity allocation, charging) being given to an infrastructure manager but daily network administration (e.g. maintenance) being the responsibility of the major undertaking. European legislation now requires a minimum of separate accounts for infrastructure and operations as well as separation of powers. Key decisions regarding infrastructure charging and slot allocation should be taken out of the hands of any infrastructure manager that is also involved in train operations as an integrated company (Nash, 2008).

Governments undertake full separation in order to maintain ownership and control over the railway network while still encouraging greater contestability and private sector participation in train services. However, this option adds transaction costs and regulatory burdens (World Bank, 2011). Other costs involve infrastructure maintenance or responsibility for delays (Shires et al., 1994). On the other hand, integrating the two parts opens the possibility of low transparency about costs or capacity allocation. It also permits cross-subsidization, where certain loss activities are financed by other profitable activities leading to allocation inefficiency (Deville and Verduyn, 2012), which is clearly demotivating. There is also a risk that the infrastructure provider will act in a discriminatory fashion towards its competition. Integration complicates regulation of the infrastructure monopoly and can create lower or misguided performance incentives. In contrast, an integrated form facilitates improved coordination of maintenance and modernization (cost savings and synergies resulting from shared facilities and service), simplifies operational coordination and conflict resolution, and brings increased comprehension of investment incentives. The coexistence of integration and competition drives technological and product innovation (Ksoll, 2004). Economic theory does not give any clear conclusions about whether vertical separation or integration is better for railway efficiency. Some answers can be found in the empirical analysis (see Section 2).

\subsection{Horizontal separation}

In accordance with the European railway reforms, horizontal separation is taken as the separation of passenger and freight transport. Passenger and freight transport in Europe strongly differ in their potential for profitability. Freight transport is expected to be profitable. Passenger transport is usually unprofitable (or usually operates at a loss) and requires subsidies. The compensation passenger transport receives from profits from freight transport has a negative motivation effect on freight transport and lowers its competitiveness. Synergies from operating similar types of transport represent the main advantage of horizontal integration. It is therefore not clear which option is superior. 
Some conclusions can be formed on the basis of available empirical studies (see Section 2).

Most EU countries continue in the traditional scheme of integrated passenger and freight transport within a holding company to ensure lower costs. Most EU countries (Austria, Belgium, Bulgaria, the Czech Republic, Finland, France, Germany, Greece, Ireland, Italy, Lithuania, Luxembourg, Poland, Portugal, Slovenia, Spain) remain horizontally integrated, while only nine countries (Denmark, Estonia, Hungary, Latvia, the Netherlands, Romania, Slovakia, Sweden, Great Britain) have implemented horizontal separation.

\subsection{Entry of competition}

Entry of competition into operating services is a major reform component for European railways. Competition arises when two or more subjects aim to obtain something which cannot be held by everyone at once. They are motivated by some profit or welfare. These subjects endeavour to lower costs and choose strategies to increase demand for their goods or services. These actions usually benefit customers. The pressure of competition forces producers to be more efficient, which is good for aggregate efficiency. Growing competition means a rising number of competitors or lowered costs, which is joined by growth in total factor productivity and forces producers to innovate over time (Vickers, 1995).

Entry of competition can be implemented in the railway sector in two forms - competition for the market and competition in the market. The first is also called competitive tendering and is carried out via public tenders for providing subsidized services. The tenders are organized by such authorities as ministries and regions. The process should lead to improved quality in provided services and a decrease in requested subsidies in comparison with direct assignment to the incumbent. It also ensures some control over the range and quality of provided services is maintained by public authorities. It is considered a suitable type of competition in railway transport.

The latter form is also known as open access. In this situation, the market is open, there is free entry for new entrants, and operations are not subsidized from public resources. This type of competition is suitable for sufficiently large markets and is only applicable on potentially profitable routes. It has been implemented particularly in freight transport, as most passenger routes are not profitable. It can be found mostly on the most lucrative passenger routes, e.g. the route from Prague to Ostrava in the Czech Republic. It is not clear whether this type of competition is suitable in passenger transport in general.

All EU countries have had free entry in freight transport since 2007. On the other hand, direct contracting of subsidized services to incumbents prevails in passenger transport, though competition is gradually coming also to the segment of passenger transport. EU countries are not generally opening themselves very much to competition - passenger transport is not a lucrative branch and barriers to entry of competition still persist. Things may change after the Fourth Railway Package has come into practice. 


\subsection{Competition in the EU}

Some European countries have quite extensive experience with competitive tendering in the segment of passenger transport, as is the case in Great Britain and Sweden (all subsidized services), and Germany (a growing proportion of subsidized regional services). Other countries also have some experience with this type of competition but it is not as extensive; failures during negotiating processes occurred in multiple countries (e.g. in the Czech Republic). On the other hand, experience with open access competition in passenger transport is much more limited and only a few countries have experienced this type of competition.

Today, open access competition can be found in only seven EU countries - Great Britain, Germany, Italy, Austria, the Czech Republic, Slovakia, and Sweden. Only two countries have more than one competitor (in addition to the incumbent) - the Czech Republic and Slovakia.

Open access competition in Great Britain is allowed but strongly regulated. It can be found on routes connecting London with cities which had not previously been joined directly by railway to London (see Table 1 ). The market share is low - about $1 \%$ of all operations (Griffiths, 2009). Italy is the first European country with open access competition on a high-speed route (since April 2012). Competition caused a sharp decline in prices and thus a significant increase in the number of passengers (Cascetta and Coppola, 2013). In Germany, regional and long-distance traffic is strictly separated. Longdistance transport is operated without subsidies and open access competition is allowed. Despite this fact, over 99\% of the market share is in the hands of Deutsche Bahn (Deville and Verduyn, 2012). The majority of new competitors who have tried to enter the market have not succeeded; there are several operators in niche markets (European Commission, 2013a). This may be due to high costs for entry into infrastructure (Link, 2004) or discrimination against new entrants by Deutsche Bahn DB (Nigrin, 2014). In Austria, a major route has been operated by a private company alongside the incumbent since 2011. It resulted in a decline in prices and an increase in the frequency of connections (Komárek, 2014). The Swedish market for passenger railway services has been open to competition since the year 2010. It was not very widespread as it was mostly financially unattractive (see Table 1). The impact on the Swedish railway market is small (European Commission, 2013a). The incumbent (SJ) has only faced substantial competition since MTR Express entered the Stockholm-Gothenburg line (Vigren, 2016) - see Table 1. The income of new competitors has brought lower prices and product differentiation, and the situation is improving with the entry of the next competitor. There has been open access competition in the Czech Republic with two operators since September 2011 and with three operators since December 2012. Tomeš et al. (2016) mapped the implications of competition implementation in the Czech Republic. A considerable decline in prices and subsequent accusations of unfair practices by the competitor, pressure on infrastructure capacity, and benefits for customers were the most important impacts. The situation in Slovakia is hard for competitors as students and pensioners can travel at no cost. Open access competition in passenger transport in Slovakia began in December 2014 with the entry of Czech operators (see Table 1). Prices declined immediately, while the quality of services as well as the frequency of connections increased. 
Table 1 summarizes the state of open access competition in the only 7 EU countries with this type of competition in Europe (operator's name, date of entry, current routes, excluding airport only operators). It also summarizes the utilization of competitive tendering in these countries.

Table 1 Summary of competition implementation in countries with open access

\begin{tabular}{|c|c|c|}
\hline Country & Open access & Competitive tendering \\
\hline Austria & Westbahn, Dec 2011 (Wien-Salzburg) & $\begin{array}{l}\text { Not utilized; directly } \\
\text { assigned to ÖBB or small } \\
\text { operators owning local } \\
\text { routes }\end{array}$ \\
\hline Czech Republic & $\begin{array}{l}\text { RegioJet, Sep } 2011 \text { (Prague-Ostrava, Prague- } \\
\text { Brno(-Bratislava)); Leo Express, Dec } 2012 \text { (Prague- } \\
\text { Ostrava) }\end{array}$ & Limited \\
\hline Germany & $\begin{array}{l}\text { InterConnex, Dec 2001-Dec } 2014 \text { (Leipzig-Berlin- } \\
\text { Rostock); HBX, Dec } 2005 \text { (Berlin-Thale, Berlin-Goslar); } \\
\text { Alex, Dec } 2007 \text { (Munich-Regensburg(-Prague)); HKX, Jul } \\
2012 \text { (Hamburg-Köln); Locomore, Dec 2016-May } 2017 \\
\text { (Berlin-Stuttgart) }\end{array}$ & $\begin{array}{l}\text { Widespread; tenders or } \\
\text { direct assignment - } \\
\text { around } 2 / 3 \text { directly to } \\
\text { Deutsche Bahn (Hunold } \\
\text { and Wolf, 2013) }\end{array}$ \\
\hline Great Britain & $\begin{array}{l}\text { First Hull Trains, Sep } 2000 \text { (Hull-London); Grand Central, } \\
\text { Dec } 2007 \text { (Sunderland-London, Bradford-London); Wrex- } \\
\text { ham \& Shropshire, Jan 2008-Jan } 2011 \text { (Wrexham- } \\
\text { London); }\end{array}$ & Widespread \\
\hline Italy & $\begin{array}{l}\text { Arenaways, Nov 2010-Feb } 2012 \text { (Milan-Turin); NTV, Apr } \\
2012 \text { (Turin-Salerno, Venice-Salerno, Brescia-Napoli) }\end{array}$ & Limited \\
\hline Slovakia & $\begin{array}{l}\text { RegioJet, Dec } 2014 \text { (Prague-Košice); Leo Express, Dec } \\
2014 \text { (Prague-Košice) }\end{array}$ & Limited \\
\hline Sweden & $\begin{array}{l}\text { Snälltåget, } 2010 \text { (Malmö-Stockholm-Uppsala (-Åre)); } \\
\text { Öresundståg, Dec } 2011 \text { (Gothenburg-Malmö- } \\
\text { (Copenhagen)); MTR Express, Mar } 2015 \text { (Gothenburg- } \\
\text { Stockholm); (BlåTåget, Dec } 2011 \text { (Gothenburg-Stockholm- } \\
\text { Uppsala)) }\end{array}$ & Widespread \\
\hline
\end{tabular}

Sources: European Commission, 2013a; European Commission, 2016b; Tomeš and Jandová, 2015; Tomeš, 2016;

When we look more closely at the data concerning market opening (contained in European Commission, 2016b), we find the following information. The market share of competitors in the passenger market in 2014 (in percentage of passenger-kilometres) was highest in Great Britain (nearly 90\%), then in Poland (about 55\%), next in Italy (nearly 20\%), and at around 10\% in Germany, Austria, Latvia, Norway, and Romania. Competition in some form was present at least at 15 countries, while it was absent from 10 countries. The market shares of competitors in this market segment are lower than those in the freight segment due to different stages of market opening. In most countries, incumbents maintain a market share of over $80 \%$. 
For comparison, the market share of competitors in the freight market in 2014 (in percentage of tonne-kilometres) was highest in Great Britain and Sweden (around 55\%); then in Bulgaria and Norway (nearly 50\%); next in Romania, Italy, and the Netherlands (around 40\%); then in Hungary, France, Poland, and Germany (more than 30\%); and at around 30\% in Estonia and the Czech Republic. It is absent from only five countries (European Commission, 2016b). When we look at the percentage change over the past three years, competitor market shares have continued to increase with only three exceptions (Latvia, Estonia, and Romania).

\section{Review of empirical studies}

A number of studies about the impact of the European railway reforms on railway efficiency have been conducted, but they have not reached universal conclusions. Most studies concerning horizontal separation identified a positive effect on efficiency. The impact of competition entry was mostly positive, but it was negative in some studies. The impact of vertical separation is completely unclear.

Cantos Sánchez (2001) examined 12 Western European countries during 1973-1990. He investigated whether vertical separation or integration should be carried out. The study found that costs related to freight transport and infrastructure are complementary, while those deriving from passenger transport and the infrastructure are substitute. The results were obtained only for vertically integrated companies. Driessen et al. (2006) carried out an analysis using data for 13 Western European countries during 1990-2001. They deduced that in passenger transport competitive tendering raised efficiency while open access lowered efficiency. The impact of vertical integration was identified as positive. Wetzel (2008) examined 22 European countries during 1994-2005. She deduced that the impact of competition entry on domestic freight transport market efficiency was positive, whereas competition entry into the international transport and domestic passenger market had a negative effect. The existence of an independent regulating body affected efficiency in a positive way. Vertical separation and horizontal separation did not have statistically significant effects. Uncompleted reforms in Western European countries deteriorated final efficiency. The author identified differences in efficiency between Eastern and Western European countries. Growitsch and Wetzel (2009) devoted their research to 27 European countries during 2000-2004. They found a moderate positive effect of vertical integration on efficiency. Asmild et al. (2009) investigated 23 European countries during 1995-2001. They examined how railway reforms affect the inefficiencies of specific cost drivers. Their main findings were that the reforms generally improved technical efficiency but with different effects for different cost items. Accounting separation is important for improving the efficiency of both material and labour costs, whereas other reforms influenced only one of these factors. Entry of competition into passenger transport had a positive impact, but competition was present only in four countries and so this result should not be generalized. Joined positive effect of competition in freight transport (for both cost items) was only weakly significant. This study also examined differences between Western and Eastern European countries, especially those owing to lower productivity and wages in the east. Friebel et al. (2010) dealt with the impact of the order of implemented reforms in 12 Western European countries during 1980-2003. They found that competition entry, constitution of an independent regulating body, and vertical separation increased efficiency. Howev- 
er, the sequence in which reforms were implemented was important. Simultaneous implementation of reforms decreased efficiency, while gradual application raised efficiency. They were unable to distinguish the impact of particular reforms owing to a lack of precise data - only the official dates of implementation were known, not the actual rate of utilization in practice. Cantos Sánchez et al. (2010) examined the influence of reforms on efficiency, productivity, and technological progress in 16 Western European countries during 1985-2004. They found a generally positive impact from reforms, but it was statistically significant only for countries which had completed both vertical and horizontal separation. They found that vertical separation increased efficiency, productivity, and technological progress. Improvements were more substantial with simultaneous horizontal reforms. Only when the industry's horizontal structure was modified and competition systems were introduced did higher competitive pressure in the sector also lead to more efficient behaviour by operators. Horizontal separation on its own did not have generated appreciable improvements, but this was the case only for two railway systems. Cantos Sánchez et al. (2012) tested out two efficiency estimation techniques (data envelopment analysis and stochastic frontier analysis) in 23 European countries during 2001-2008. The most efficient countries were those which had finished the major reform points because particular reforms are strongly complementary. The impact of vertical separation was positive but statistically significant for only one of the eight models tested. The impact of competition was positive and statistically significant but only without imposition of a variable integrating all reforms. Horizontal reforms by themselves may increase efficiency, but a significant impact on efficiency is produced when horizontal and vertical reforms are combined. Impacts of the reforms on efficiency improvement were clearly greater when the entire package of reforms was introduced. Mizutani and Uranishi (2013) studied the impact of horizontal and vertical separation on costs in 23 European and East Asian OECD countries during 1994-2007. Horizontal separation decreased costs. The effect of vertical separation depended on transport density. Vertical separation lowered costs for low transport density (low coordination costs) and raised costs for high transport density (high transaction costs). Bougna and Crozet (2016) used a stochastic distance function to measure efficiency and productivity changes and calculated the decomposition of total factor productivity for 17 European countries during 1997-2011. They determined that vertical separation and entry of competition in freight transport had no impact on efficiency while entry of competition into passenger transport (competitive tendering) had a significant positive impact. They concluded that the liberalization process is not a key success factor for productivity of the railway industry.

As the results in the literature are not straightforward, Table 2 presents a summary of their conclusions. As is clear from Table 2, most studies examined the effects of vertical separation, but the impact of this factor remains rather unclear. It seems to be dependent on other factors such as the completeness and sequence of implemented reforms, train density, and the given country's specific features. Horizontal separation seems to have mostly a positive effect. Entry of competition produces mostly a positive effect, but in some studies it is negative or unclear in certain circumstances. The ambiguity of the results may stem from the facts that the samples of countries are different and the investigated period is not relevant for certain countries that implemented reforms later, thus preventing the reforms' results from being visible in the data available. 
Table 2 Summary of empirical studies

\begin{tabular}{|c|c|c|c|c|c|c|}
\hline Study & Period & $\begin{array}{l}\text { Sample countries } \\
\text { (number, region) }\end{array}$ & VS & $\mathrm{HS}$ & P EoC & F EoC \\
\hline Cantos Sánchez, 2001 & $\begin{array}{l}1973- \\
1990\end{array}$ & 12, WE & $-F /+P$ & & & \\
\hline Driessen et al., 2006 & $\begin{array}{l}1990- \\
2001\end{array}$ & 13, WE & + & & $+\mathrm{CT} /-\mathrm{OA}$ & \\
\hline Wetzel, 2008 & $\begin{array}{l}1994- \\
2005\end{array}$ & 22, E & 0 & 0 & - & + D/- INT \\
\hline $\begin{array}{l}\text { Growitsch and Wetzel, } \\
2009\end{array}$ & $\begin{array}{l}2000- \\
2004\end{array}$ & 27, E & - & & & \\
\hline Asmild et al., 2009 & $\begin{array}{l}1995- \\
2001\end{array}$ & $23, E$ & 0 & & + & + \\
\hline Friebel et al., 2010 & $\begin{array}{l}1980- \\
2003\end{array}$ & 12, WE & + & & + & + \\
\hline $\begin{array}{l}\text { Cantos Sánchez et al., } \\
2010\end{array}$ & $\begin{array}{l}1985- \\
2004\end{array}$ & 16, WE & + & $+(+V S)$ & $+(+V S, H S)$ & $+(+V S, H S)$ \\
\hline $\begin{array}{l}\text { Cantos Sánchez et al., } \\
2012\end{array}$ & $\begin{array}{l}2001- \\
2008\end{array}$ & $23, E$ & 0 & $+(+V S)$ & + & + \\
\hline $\begin{array}{l}\text { Mizutani and Uranishi, } \\
2013\end{array}$ & $\begin{array}{l}1994- \\
2007\end{array}$ & $21, E+2, E A$ & $?$ & + & & \\
\hline $\begin{array}{l}\text { Bougna and Crozet, } \\
2016\end{array}$ & $\begin{array}{l}1997- \\
2011\end{array}$ & $17, \mathrm{E}$ & 0 & & + & 0 \\
\hline
\end{tabular}

Following notation is used: $\mathrm{WE}=$ Western Europe, $\mathrm{E}=$ Europe, $\mathrm{EA}=$ East Asia. $\mathrm{VS}=$ vertical separation, $\mathrm{F}=$ freight transport, $\mathrm{P}=$ passenger transport, $\mathrm{HS}=$ horizontal separation, $(+\mathrm{VS})=$ together with vertical separation, $(+\mathrm{VS}, \mathrm{HS})=$ together with vertical and horizontal separation. $\mathrm{EoC}=$ entry of competition, $\mathrm{CT}=$ competitive tendering, $\mathrm{OA}=$ open access, $\mathrm{D}=$ domestic transport, $\mathrm{INT}=$ international transport. $+=$ positive effect, $-=$ negative effect, $0=$ no effect found, ? = unclear effect (i.e. positive under some circumstances and otherwise negative). Empty fields denote untested features.

\section{Measuring efficiency}

In economic theory, a situation is considered effective if it is not possible to produce more of one good with given resources without decreasing production of another good, i.e. when there is no waste. A firm or economy operates on a production possibility frontier. In quantitative analysis, efficiency is understood as the ratio of (weighted) outputs to (weighted) inputs for the examined production process. The production possibility frontier determines the maximum rate of efficiency achievable given available technologies (Jablonský, 2004). Many companies in the railway industry operate markedly below the production possibility frontier. Measuring efficiency and identifying sources of inefficiency are the main prerequisites for improving the behaviour of subjects in a competitive environment.

We distinguish among allocation, technical, and dynamic efficiency. Allocation efficiency is measured via total welfare, under the assumption that inputs are utilized in the 
right proportions. Technical efficiency means for a redundant amount of inputs not to be utilized for a given output level (or to produce the maximum output for given inputs) (Jablonský, 2004). A fully efficient unit must be efficient from both the allocation and the technical point of view. Dynamic efficiency includes the possibility of technological change over time and thereby also a shift in the production possibility frontier (Cooper et al., 2007).

The railway industry utilizes several inputs and produces several outputs. Railway inputs usually comprise the average number of employees, length of lines, and number of locomotives, railcars, coaches and wagons. Railway outputs usually include the annual transported passenger-kilometres, passenger-train-kilometres or number of passengers, and tonne-kilometres or train-tonne-kilometres. Currently, the most widely used methods able to handle this type of problem are data envelopment analysis (DEA) and stochastic frontier analysis (SFA).

DEA is a very popular method for measuring the efficiency of railways. It represents an application of linear programming. It forms a frontier and judges the efficiency of each investigated unit relative to this frontier. There are many types of DEA models. They differ especially in their type of returns to scale.

Models utilized within DEA have efficiency scores between 0 and 1 . A unit with a value of 1 is considered efficient, while units with scores below 1 are inefficient (Cooper et al., 2011). Efficiency scores can serve to create a list of units (companies) according to their scores, which can help in identifying the main factors of success or failure. These scores can be subsequently applied in research on economic and other factors influencing efficiency, e.g. product per capita, railway network density, and reform implementation. Usually a regression analysis using the Tobit model is employed.

An advantage to DEA is that it does not require information about input and output prices, which is difficult to obtain for railways. DEA works with physical input and output units. It assumes homogeneity within the investigated units. In addition, DEA does not require any parametric specification. It enables particular factors to be analysed separately. On the other hand, its results may be biased by outliers and measurement errors. Moreover, units that are non-homogeneous (those with very different characteristics) can cause problems.

SFA is a parametric method for estimating the production possibility frontier. The method operates with two stochastic components - the first component represents measurement error, while the second captures inefficiency (Coelli et al., 2005). It requires parametric specification of a production or cost function. Either the CobbDouglass production function or a transcendental logarithmic function is usually used. It is a stochastic method and thus less sensitive to outliers than DEA is. Its main disadvantage is its need for a concrete parametric form for the production/cost function and a sufficient number of observations. Its main advantage lies in its better explanation of the data.

\section{Problems connected to evaluating the impacts of reforms}

It is an open question whether it is possible to reach a large degree of competition without enormous costs. Things that work at certain times and in certain industries do not 
necessarily work elsewhere at a different time (Pittman, 2005). There are, for example, many factors that might cause a negative effect on efficiency or welfare from increased competition.

\subsection{Important questions}

Before evaluating the impact of the European railway reforms, it is useful to look at some important considerations. One basic question is: "Does competition implementation via the European railway reforms lead to increased efficiency?" But we should not forget to bear in mind the assumptions which form the pillars of the analysis. Some important questions emerge. Which variable will indicate the answer and how can we measure it? Under which conditions is it the case? How long after official implementation will it be measurable? Is the sequence of the reforms' implementation important? Is it essential to finish all reforms, or is it possible to evaluate the impact of particular reforms separately? What are the costs associated with the reforms? What market share size is necessary to consider that competition exists? Or should we consider several levels of competition? How should we set the levels of competition reasonably? Should we examine passenger and freight transport separately? And domestic and international transport? And what about main routes versus niche markets? Will the impact of the reforms be the same in fully developed economies with functioning market mechanisms as in former Eastern Bloc countries which experienced a transformation process? Is a division into Western and Eastern European countries suitable/sufficient? Or can we neglect all of these differences and examine all EU countries together as homogeneous units to capture the main features?

\subsection{Specific properties of the railway market}

The railway services market has some specific properties. There is general agreement that the network has features of a natural monopoly but also that transport operational services can be provided on the basis of competition. Most of the services (68\% of the passenger-kilometres in EU 28 in 2014) in passenger transport are subsidized and considered to be a public service obligation (European Commission, 2016b). Only the most desirable routes can be operated on the basis of competition. The ecological point of view is also very important, as is the long-term sustainability of development in the area of transport. Economic policy is under pressure from a lobby which can be quite strong, as railways employ many people. The interdependence between policy and railways may slow down potential changes in the existing rigid system. Incumbents are too big and ineffective. Separating an incumbent into a small number of parts would enable their cooperation against new entrants, which would inhibit competition. Separating the incumbent into many parts could bring greater competition and more equal chances for other competitors but probably also high costs for implementing such a change. The ideal solution is unclear.

\subsection{Problems with data}

The next source of problems is related to the data available. Most studies measuring the efficiency of railways use data from the International Union of Railways (UIC). There are some problems connected to this data, some of which may be overcome by researchers collecting their own data from respective national sources, as this data is mostly accessible, but this process is highly time consuming. 
The main problems associated with the UIC data are described in Nash (2013). Data from UIC usually cover information about the state incumbent in each country. Data from Great Britain, which is the furthest along in the reform process, are not available. Some data, e.g. some details about the number of rolling stock and staff, are incomplete or misleading. In some cases, data include subsidiaries in other countries, and thus the geography of the combined infrastructure and operations is not consistent. The actual state of implemented reforms may differ from the formal date of implementation - this difference may be even several years.

Open access competition operates only on some potentially lucrative routes, and so the amount of data available is rather small. Currently, it has been implemented in only seven EU countries and its market share is small. Competitive tendering has been implemented more frequently, but it is often strongly regulated and succeeding in the tenders can be very costly. It mostly occupies only a small share of the market (with some exceptions such as in Great Britain). For this reason, relatively little data concerning competition are available, making analysis difficult.

Analyses usually use official dates of entry of the first competitor, while some studies have regarded competition as existing after a certain market share has been gained. But there is not much discussion regarding whether it is correct and what implications are produced by such decisions. Studies investigating vertical separation do not usually address whether it was complete separation or separation of key powers and also do not consider other such aspects as equal chances for other competitors.

Such data are available only with a large delay. Reforms are still in progress in many countries. Although reforms have been completed in some countries, competition implementation is a gradual process and it takes many years to get the changes into common practice. The difference between the establishment of a given arrangement and its practical use could be quite large. It usually takes many months or even several years until the first outcomes become visible. It is also often not clear which dates were used in empirical analyses of reform implementation. Based on data from IRG-Rail (2016), it is possible to compute the time elapsed from the establishment of a reform supporting competition until the entry of the first new competitors. In the freight market, it took an average of 31 months (data for 18 EU countries), while in the passenger market it was around 37 months (data for 13 EU countries). It could be debated how these facts could have influenced the results of the studies analysed herein.

Collection of a current, accurate, and complete dataset is an important task for further analysis and could aid in a more precise evaluation of the impact of the EU railway reforms on efficiency.

\subsection{Computations}

The methods utilized for efficiency evaluation stand on some assumptions which are not always met in reality. Violation of some of these assumptions is not necessarily crucial, but some of them may be essential and fundamental. The method which is utilized most often is DEA. It supposes the homogeneity of the investigated units (countries). Eastern and Western European countries differ quite a lot, however, as they have come through different historical development. Due to this fact, they have different structures of the market, industry, transport, institutional environment, quality of staff and capital equip- 
ment, and so on. Some countries are spacious with low network density, while others, such as the Czech Republic, are small with high network density. Some countries are oriented towards freight transport, particularly for transporting raw materials (as is the case for Baltic countries), while others are instead oriented towards passenger transport (as is the case for Spain). Does this matter?

The next problem consists of obtaining sufficient data for computations. Reforms have been implemented gradually, and it generally took several years after implementation to see some results in the data and then even more time until the new data were published. At the beginning of 2017, only complete official railway data for 2012 from UIC were available.

In addition, data concerning utilized inputs are a bit debatable. DEA does not work with prices but with physical units. Is it possible to consider a train in Austria the same as a train in Romania? Or a worker in France identical to one in Bulgaria?

The choice of model, particularly the type of returns to scale in DEA, is also somewhat controversial. Should they be constant or variable or in any way alternatively defined? Each type of model has its pros and cons. But how shall we decide on the basis of available data? Use of SFA is also somewhat problematic as the concrete form of the cost/production function is unknown and its parameters must be estimated. For railways, however, it is particularly hard to obtain data concerning costs, so this disadvantage may in some cases outweigh the advantages to using SFA.

After reading many empirical studies, another aspect to efficiency evaluation appears. These studies often do not explicitly state how they dealt with the time dimension to the data, and the reader must make a large effort to understand it. Sometimes, all of the data are put together regardless of the time dimension, which has several important implications. The number of observations substantially increases. The time dimension is not employed - the data is considered to be cross-sectional. The shift in the productivity frontier over time is not taken into consideration. Each country is used several times in the process of constructing the frontier. All of these facts obviously have substantial impacts on the results.

\subsection{Some proposals}

It is important to be aware of potential sources of ambiguity or problems when analysing the impact of competition on railway efficiency. Doing so may aid in understanding the results of empirical studies more accurately. It may be possible at a later date, when there is more complete data from all EU countries with completely implemented reforms with a larger market share for competitors, to make decisions about whether the reforms can be judged as successful. Maybe an analysis using different approaches could also help to answer the key question.

\section{Conclusion}

This paper endeavoured to evaluate the impact of the European railway reforms on the efficiency of railways in the EU on the basis of existing empirical studies evaluating the situation in EU countries. It also tried to identify the main factors making the impacts of these reforms difficult to measure. 
The EU reforms most often took the form of vertical separation, horizontal separation, and two types of entry of competition - competition for the market and competition in the market. Based on the studies available, the effect of vertical separation is completely unclear. Horizontal separation seems to have had a mostly positive effect. As far as entry of competition is concerned, a more positive effect has prevailed (in both passenger and freight transport).

Competition is mostly beneficial for consumers, but its overall effect depends on other factors. As is apparent from the situation in certain countries, competition for the market (competitive tendering) could represent a better way of competition implementation, even though it is not very developed in some countries. Competition on the market (open access) has developed in only a few countries and on only a minimal number of routes. It is mostly positive for consumers, but the overall social effect depends on other features of the environment. Some countries have seen accusations of unfair practices from competitors or price wars.

As the results of existing empirical studies do not always match and often give unclear conclusions about the impact of the implemented reforms, it is interesting to examine the potential sources of the empirical studies' differing findings. The largest problem probably lies in the data used in the analyses, while other problems can be seen in the diversity of the countries, their market mechanisms, institutional environments, traditions, and so on, as well as the different properties and potential possibilities of various types of transport and some specifics of the railway transport market.

Policymakers should not only enable entry of competition with a view towards higher efficiency of railway transport. They should also concurrently specify the rules to gain the greatest welfare benefits from competition implementation while taking into account particular features of their country. Entry of competition does not automatically mean that operators will have an interest in implementing services, and without a vision of the sustainability of future development operators will not be motivated to enter the industry and policymakers' efforts will be wasted.

Over the course of time, it will probably be possible to judge the impact of the European railway reforms more precisely. It depends on when the implemented reforms will become more evident in practice and consequently in the data available. The sooner we can evaluate these impacts correctly, the smaller will be the costs of potential corrections to some undesirable effects.

Disclosure statement: No potential conflict of interest was reported by the author. 


\section{References}

Asmild, M., Holvad, T., Hougaard, J. L., Kronborg, D. (2009). Railway reforms: Do they influence operating efficiency? Transportation, 36(5), 617-638. DOI: 10.1007/s11116-009-9216-x

Bougna, E., Crozet, Y. (2016). Towards a liberalised European rail transport: Analysing and modelling the impact of competition on productive efficiency. Research in Transportation Economics, 59, 358-367. DOI: 10.1016/j.retrec.2016.07.014

Cantos Sánchez, P. (2001). Vertical relationships for the European railway industry. Transport Policy, 8(2), 77-83. DOI: 10.1016/S0967-070X(00)00039-1

Cantos Sánchez, P., Pastor, J. M., Serrano, L. (2010). Vertical and horizontal separation in the European railway sector and its effects on productivity. Journal of Transport Economics and Policy, 44(2), 139-160.

Canots Sánchez, P., Pastor J. M., Serrano, L. (2012). Evaluating European railway deregulation using different approaches. Transport Policy, 11(24), 67-72. DOI: 10.1016/j.tranpol.2012.07.008

Cascetta, E., Coppola, P. (2013). Competition on fast track: An analysis of the first competitive market for HSR services. Procedia - Social and Behavioral Sciences, 111, 176-185. DOI: 10.1016/j.sbspro.2014.01.050

CER. (2011). Public service rail transport in the European Union: An overview. http://www.cer.be/sites/default/files/publication/2265_CER_Brochure_Public_Service_ 2011.pdf

Coelli, T. J., Rao, D. S. P., O’Donell, C. J., Batesse, G. E. (2005). An Introduction to Efficiency and Productivity Analysis. 2nd Ed. New York: Springer.

Cooper W. W., Seiford, L. M., Zhu J. (2007). Data Envelopment Analysis: A Comprehensive Text with Models, Applications, References and DEA-Solver Software. New York: Springer.

Cooper, W. W., Seiford, L. M., Zhu, J. (eds.) (2011). Handbook on Data Envelopment Analysis. New York: Springer.

Deville, X., Verduyn, F. (2012). Implementation of EU legislation on rail liberalization in Belgium, France, Germany and The Netherlands. Brussels: National Bank of Belgium. (Working Paper No. 221) http://aei.pitt.edu/34882/1/wp221En.pdf

Driessen, G., Lijesen, M. G., Mulder, M. (2006). The impact of competition on productive efficiency in European railways. The Hague: CPB Netherlands Bureau for Economic Policy Analysis. (CPB Discussion Paper 71) http://www.cpb.nl/en/publication/impact-competition-productive-efficiency-europeanrailways

European Commission. (2001). European transport policy for 2010: time to decide. Luxembourg: Office for Official Publications of the European Communities. White Paper.

https://ec.europa.eu/transport/sites/transport/files/themes/strategies/doc/2001_white_pap er/lb_com_2001_0370_en.pdf 
European Commission. (2013a). Proposal for a Regulation of the European Parliament and of the Council amending Regulation (EC) No 1370/2007 concerning the opening of the market for domestic passenger transport services by rail. Brussels: European Commission. http://eur-lex.europa.eu/legal-content/EN/TXT/PDF/?uri=CELEX:52013 PC0028\&from $=\mathrm{EN}$

European Commission. (2013b). European Railways at a junction: The Commission adopts proposals for a Fourth Railway Package. Brussels: European Commission. http://europa.eu/rapid/press-release_IP-13-65_en.htm

European Commission. (2016a). Statistical Pocketbook 2016: EU transport in Figures. Brussels: European Commission. DOI: 10.2832/809634

European Commission. (2016b). Fifth report on monitoring developments of the rail market. Brussels: European Commission. http://eur-lex.europa.eu/legalcontent/EN/TXT/PDF/?uri=CELEX:52016SC0427\&from=EN

Friebel, G., Ivaldi, M., Vibes, C. (2010). Railway (de)regulation: A European efficiency comparison. Economica, 77(305) 77-91. DOI: 10.1111/j.1468-0335.2008.00739.x

Griffiths, T. (2009). On rail competition: The impact of open access entry on the Great Britain rail market. In: Beck, A., Veeneman, W., van den Velde, D. (eds.). Beyond Competitive Tendering - Proceedings of the_Eleventh International Conference on Competition and Ownership in Land Passenger Transport. Delft: Next Generation Infrastructures Foundation.

Growitsch, C., Wetzel, H. (2009). Testing for economies of scope in European railways: An efficiency analysis. Journal of Transport Economics and Policy, 43(1) 1-24.

Hunold, M., Wolf, C. (2013). Competitive procurement design: Evidence from regional passenger railway services in Germany. Mannheim: ZEW Centre for European Economic Research. (ZEW Discussion Paper No. 13-009) http://ftp.zew.de/pub/zewdocs/dp/dp13009.pdf

Ivaldi, M. (2005). Restructuring railways: In theory and practice. CESifo DICE Report, 3(4), 3-9.

IRG-Rail. (2016). Fourth Annual Market Monitoring Report. Paris: Independent Regulators' Group - Rail. http://www.irg-rail.eu/public-documents/2016/

Jablonský, J., Dlouhý, M. (2004). Modely hodnocení efektivnosti produkčních jednotek. Prague: Professional Publishing.

Johnson, D., Nash, C. (2012). Competition and the provision of rail passenger services: A simulation exercise. Journal of Rail Transport Planning \& Management, 2(1), 14-22. DOI: 10.1016/j.jrtpm.2012.09.001.

Komárek, O. (2014). Open Access Konkurence na Trati Wien - Salzburg (Master's thesis). Brno: Masaryk University.

Ksoll M. (2004). Integration of infrastructure and transport: An assessment from industrial economics and railway perspectives. Paper from 2nd Conference on Railroad Industry Structure, Competition and Investment, Evanston, IL, USA, October 2004. 
Lang, M., Lamperrouza, M., Finger, M. (2011). Competition effects in a liberalized railway market. Journal of Industry, Competition and Trade, 13(3), 375-398. DOI: 10.1007/s10842-011-0117-2

Link, H. (2004). Rail infrastructure charging and on-track competition in Germany. International Journal of Transport Management, 2(1),17-27. DOI: 10.1016/j.ijtm.2004.05.002

Mizutani, F., Uranishi, S. (2013). Does vertical separation reduce cost? An empirical analysis of the rail industry in European and East Asian OECD Countries. Journal of Regulatory Economics, 43(1), 31-59. DOI: 10.1007/s11149-012-9193-4

Nash, C. (2008). Passenger railway reform in the last 20 years - European experience reconsidered. Research in Transportation Economics, 22(1), 61-70. DOI: 10.1016/j.retrec.2008.05.020

Nash, C. (2013). Rail transport. In: Finger, M.; Holvad, T. (eds.). Regulating Transport in Europe. Cheltenham: Edward Elgar Publishing.

Nigrin, T. (2014). Open competition or discrimination on tracks? Examples of anticompetitive behaviour of the Deutsche Bahn. Review of Economic Perspectives, 14(1), 16-33. DOI: 10.2478/revecp-2014-0002

Pittman, R. (2005). Structural separation to create competition? The case of freight railways. Review of Network Economics, 4(3), 181-196.

Preston, J., Whelan, G., Wardman, M. (1999). An analysis of the potential for on-track competition in the British passenger rail industry. Journal of Transport Economics and Policy, 33(1), 77-94.

Thompson, L. S. (1997). The Benefits of Separating Rail Infrastructure from Operations. Washington, DC: World Bank. (Viewpoint: Public Policy for the Private Sector; Note No. 135)

Tomeš, Z, Jandová, M. (2015). Přístupy k liberalizaci osobní železniční dopravy v ČR. Acta Oeconomica Pragensia, 24(1). DOI: 10.18267/j.aop.499

Tomeš, Z., Kvizda, M., Jandová, M., Rederer, V. (2016). Open access passenger rail competition in the Czech Republic. Transport Policy, 47, 203-211.

Shires, J. D., Preston, J., M., Nash, C. A., Wardman, M. (1994). Rail Privatisation: The Economic Theory. Leeds: Institute of Transport Studies, University of Leeds. (ITS Working Paper 419)

Vickers, J. (1995). Concepts of competition. Oxford Economic Papers, 47(1), 1-23. http://www.jstor.org/stable/2663661

Vigren, A. (2016). Competition in Swedish passenger railway: entry in an open-access market (No. 2016: 18). CTS-Centre for Transport Studies Stockholm (KTH and VTI).

Wetzel, H. (2008). European Railway Deregulation: The Influence of Regulatory and Environmental Conditions on Efficiency. Lüneburg: Leuphana University of Lüneburg. (Working Paper Series in Economics No. 86) 
World Bank. (2011). Railway Reform: Toolkit for Improving Rail Sector Performance. International Bank for Reconstruction and Development. Washington, DC: World Bank. http://documents.worldbank.org/curated/en/529921469672181559/Railwayreform-Toolkit-for-improving-rail 